\title{
DETERMINANTY NAPLYWU BEZPOŚREDNICH INWESTYCJI ZAGRANICZNYCH DO WYBRANYCH KRAJÓW EUROPY ŚRODKOWEJ
}

DOI: $10.15290 /$ oes.2018.01.91.12

\begin{abstract}
Streszczenie
Celem artykułu jest ocena determinantów napływu bezpośrednich inwestycji zagranicznych (dalej BIZ) do państw środkowoeuropejskich (Polski, Czech i Słowacji), a zwłaszcza skutków zmian w zakresie stawek podatku dochodowego od osób prawnych, zarówno w przypadku inwestora, jak i kraju przyjmującego w latach 2010-2015. Badanie zostało oparte na modelu grawitacyjnym, który jest powszechnie wykorzystywany w badaniach z zakresu zarządzania międzynarodowego. Do badania zostały wykorzystane następujące zmienne: napływ bezpośrednich inwestycji zagranicznych (ceny bieżące, EUR), PKB (ceny bieżące, EUR), odległość geograficzna między stolicami państw, PKB per capita (ceny bieżące, EUR), różnica w stawkach podatku dochodowego od przedsiębiorstw między poszczególnymi krajami, a także zmienne zerojedynkowe określające m.in. środki płatnicze między państwami i czy posiadają wspólną granicę lub nie.
\end{abstract}

Słowa kluczowe: BIZ, model grawitacyjny, podatki, handel międzynarodowy, podatek dochodowy od osób prawnych

\section{DETERMINANT OF INFLOWS OF FOREIGN DIRECT INVESTMENT INTO THE COUNTRIES OF CENTRAL EUROPE}

\begin{abstract}
Summary
The aim of the article is to assess the determinants of inflow of foreign direct investment (FDI) to Central European countries (Poland, the Czech Republic and Slovakia), and in particular the impact of changes in corporate income tax rates, both for the investor and the host country in relation to bilateral flows of foreign capital in 2010-2015. The study was based on the gravity model, which is widely used in international management research. The following variables were used for the study: inflow of foreign direct investment (current prices, EUR), GDP (current prices, EUR), geographical distance between capitals, GDP per capita (current prices, EUR), difference in corporate tax rates between Individual countries as well as binary variables defining, inter alia, means of payment between states and whether they share a common border or not.
\end{abstract}

Key words: FDI, gravity model, corporate income tax, international trade

JEL classification: F21, F47, H25 


\section{Wstęp}

Celem artykułu jest ocena determinantów napływu bezpośrednich inwestycji zagranicznych (dalej BIZ) do wybranych państw środkowoeuropejskich (Polski, Czech i Słowacii), a zwłaszcza skutków w zakresie stawek zmian podatku dochodowego od osób prawnych, zarówno w przypadku inwestora, jak i kraju przyjmującego.

Badanie ocenia wpływ wybranych zmiennych na napływ BIZ $z$ wybranych krajów do Polski, Czech i Słowacji za pomoca panelowego modelu z równaniem grawitacyjnym w latach 2010-2015 z pominięciem kryzysu finansowego lat 20082009. Wybór Polski, Słowacji i Czech wynika z podobieństwa etniczno-kulturowego i gospodarczego, a także z małej liczby opracowań poświęconych tym krajom w badanym aspekcie. Wybrane kraje inwestorów to grupa stanowiąca średnio ponad 75\% napływu BIZ do Polski, Czech i Słowacji, a sa to: Holandia, Niemcy, Luksemburg, Francja, Hiszpania, Wielka Brytania, Włochy, Austria, Cypr i Belgia. Do badania wykorzystano różnice między stawkami podatkowymi od przedsiębiorstw w kraju inwestującym a krajem przyjmującym, jak również innych czynników wpływających na przepływy kapitału zagranicznego, takie jak PKB (ceny bieżace, EUR), odległość geograficzna między stolicami państw, PKB per capita (ceny bieżące, EUR), a także zmienne zerojedynkowe określające m.in. środki płatnicze między państwami i czy posiadają wspólną granicę lub nie.

\section{Czynniki warunkujące podjęcie oraz lokalizację zagranicznych inwestycji bezpośrednich}

Bezpośrednie Inwestycje Zagraniczne jest to specyficzny rodzaj inwestycji polegający na międzynarodowym transferze kapitału, w celu utworzenia w innej gospodarce filii zagranicznej i sprawowania nad nią kontroli [Krugman, Obstfeld, 1997, s. 124]. Również BIZ można zdefiniować jako formę długoterminowej lokaty kapitału za granica, która polega na stworzeniu w innym kraju nowego przedsiębiorstwa lub też przejęciu takiej liczby akcji przedsiębiorstwa zagranicznego, która pozwoli na jego kontrolę [Pach, 2001, s. 253]. Niektórzy jednak uważaja, że BIZ to po prostu lokata kapitału w przedsiębiorstwie zagranicznym, którego głównym powodem jest maksymalizacja zysku i osiagnięcie innych wymiernych korzyści [M. Guzek, 2006, s.114]. Wszystkie definicje łączy istotny aspekt dla BIZ, a mianowicie ich długookresowy charakter w porównaniu do inwestycji portfelowych. Do tego funkcjonowanie gospodarki światowej odbywa się pod wpływem wielkich korporacji, które przyczyniają się do umiędzynaradawiania wszystkich sfer życia [Karaszewski, 2004, s. 399].

BIZ zostało zdefiniowane przez międzynarodowe instytucie i zgodnie $z$ definicją Międzynarodowego Funduszu Walutowego to „rodzaj transgranicznych inwestycji rezydentów jednego kraju mających na celu kontrolę oraz znaczny stopień wpływu na zarządzanie przedsiębiorstwem znajdującym się na terenie innego kraju" [Między- 
narodowy Fundusz Walutowy, 2009, s. 100]. Podręcznik OECD określa dokładnie, że za BIZ uważa się inwestycje, które zapewniają inwestorowi 10\% głosów lub więcej, ponieważ próg $10 \%$ pozwala uznać udział inwestora w zarządzaniu za wystarczający. BIZ to inwestycje podejmowane przez przedsiębiorstwa oraz osoby fizyczne będące rezydentami jednego państwa w nowe lub istniejące już przedsiębiorstwo w innym kraju. Zamiarem inwestorów jest długotrwałe sprawowanie kontroli nad przedsiębiorstwem oraz osiaganie zysków [OECD, 2010, s. 7-9].

Wśród najważniejszych zalet związanych z obecnością inwestorów zagranicznych w kraju goszczacym jest zaspokojenie potrzeb, głównie w zakresie:

a) uzupełnienia niedoboru kapitałowych wynikających z niedostatecznych oszczędności wewnętrznych,

b) technologicznego unowocześnienia gospodarki,

c) wzrostu zdolności eksportowej,

d) zmniejszenia bezrobocia przez generowanie popytu na rynku pracy,

e) intensyfikacji gospodarczej regionów słabiej rozwiniętych [Karaszewski, 2004, s. 72].

Inwestycje podejmowane za granica przez firmy sa rezultatem różnych motywów, które jest trudno jednoznacznie wymienić i opisać. Jedna z teorii związana jest z procesem internacjonalizacji, która J. H. Dunning określa jako model inwestowania przedsiębiorstwa na zagranicznych rynkach, oparty na będących w jego dyspozycji specyficznych przewagach. Podjęcie BIZ wydaje się być racjonalne tylko wówczas, gdy przedsiębiorstwo posiada jednocześnie przewage własnościową przewagę lokalizacyjną oraz przewagę internalizacji. Przewaga lokalizacyjna umożliwia czerpanie zysków z obecności na danym rynku, ze względu na np. system podatkowy, mniejsze koszty produkcji i transportu, wielkość rynku zbytu, niższe ryzyko inwestycji. Przewagi te stanowią elementy eklektycznej teorii produkcji międzynarodowej sformułowanej przez J.H. Dunninga [Jarczewska-Romaniuk, 2004, s. 57].

Następnie J.H. Dunning określił i sprecyzował również cztery grupy czynników wpływających na inwestycję:

a) Inwestycje, których celem jest poszukiwanie/zdobywanie zasobów w kraju goszczącym (Resource-seeking Foreign Direct Investements).

b) Inwestycje nastawione na poszukiwanie rynków zbytu (Market-seeking Foreign Direct Investements).

c) Inwestycje zorientowane na podwyższenie efektywności (Efficiency-seeking Foreign Direct Investements).

d) Inwestycje związane z poszukiwaniem/zdobywaniem aktywów strategicznych (Strategic assets-seeking Foreign Direct Investements), Dunning, Lundan, 2008, s. 67-74].

Dzięki występowaniu niedoskonałej konkurencji międzynarodowej przedsiębiorstwa wpływają na zwiększenia przepływów czynników wytwórczych w skali międzynarodowej, a więc uzyskują nie tylko przewagi konkurencyjne, ale także je pogłębiają i utrwalaja [Zorska, 1998, s. 67]. W rezultacie przedsiębiorstwo dysponuje przewaga (własnościowa) nad pozostałymi podmiotami gospodarczymi, dążąc do jej pełnego 
wykorzystania dla własnej korzyści i podejmując się także ekspansji zagranicznej [Hymer, 1976, s. 25].

\section{Metodyka badania}

W artykule wykorzystano model grawitacyjny dla danych panelowych do oceny determinant napływu BIZ do państw Polski, Czech i Słowacji, a zwłaszcza skutków zmian w zakresie zmian stawek podatku dochodowego od osób prawnych zarówno w przypadku inwestora, jak i kraju przyjmującego. Za zmienną objaśnianą przyjęto wartości napływu BIZ (w mln EUR) w latach 2010-2015 dla Polski, Czech i Słowacji z pominięciem czasu kryzysu finansowego w latach 2008-2009. Za potencjalne zmienne objaśniające przyjęto PKB, odległość geograficzną między stolicami państw, PKB per capita, różnicę w nominalnych stawkach podatku dochodowego między krajami, różnicę w efektywnych stawkach podatku dochodowego między krajami, posiadanie wspólnej waluty, posiadanie wspólnej granicy i wskaźnik tzw. wolności handlowej.

TABELA 1.

Zmienne wykorzystane w badaniu

\begin{tabular}{|c|c|c|c|}
\hline Lp. & Nazwa & Opis & Źródło \\
\hline$\underline{1}$ & $\mathrm{BIZ}$ & $\begin{array}{l}\text { Napływ zagranicznych inwestycji bezpośrednich } \\
\text { (ceny bieżące, EUR) - w mln }\end{array}$ & OECD, Eurostat \\
\hline 2 & $\begin{array}{l}\mathrm{PKB}_{i} \\
\mathrm{PKB}_{j}\end{array}$ & $\begin{array}{l}\text { Produkt Krajowy Brutto (ceny bieżące, EUR) } \\
\text { w mln }\end{array}$ & Ameco \\
\hline 3 & ODL & $\begin{array}{l}\text { Odległość geograficzna między stolicami państw } \\
(\mathrm{km})\end{array}$ & Gogle map \\
\hline 4 & $\begin{array}{l}\mathrm{PKBP}_{i} \\
\mathrm{PKBP}_{j}\end{array}$ & $\begin{array}{l}\text { Produkt Krajowy Brutto per capita (ceny bieżące, } \\
\text { EUR) }\end{array}$ & Ameco \\
\hline 5 & GRA & $\begin{array}{l}\text { Zmienna binarna przyjmujacca wartość 1, gdy j-te } \\
\text { państwo graniczy z Polską, Czechami, Słowacją }\end{array}$ & Opracowanie własne \\
\hline 6 & Tax & $\begin{array}{l}\text { Różnica w stawkach nominalnych podatku } \\
\text { dochodowego między krajami } i \mathrm{i} j\end{array}$ & Eurostat \\
\hline 7 & EATR & $\begin{array}{l}\text { Różnica między efektywnymi stawkami opodatko- } \\
\text { wania krajami } i \mathrm{i} j\end{array}$ & Eurostat \\
\hline 8 & $\mathrm{EU}$ & $\begin{array}{l}\text { Jeżeli posiadają euro to otrzymują wartość } 1, \\
\text { w innym przypadku } 0\end{array}$ & Opracowanie własne \\
\hline 9 & $\begin{array}{l}\text { WKSW }_{i} \\
\text { WKSW }_{j}\end{array}$ & $\begin{array}{l}\text { Wskaźnik tzw. wolności handlowej (ang. trade of } \\
\text { freedom index) kraju przyjmującego } i \text { oraz inwestora } \\
j \text { w okresie t. Odzwierciedla poziom tzw. wolności } \\
\text { od ceł i barier pozataryfowych. }\end{array}$ & $\begin{array}{l}\text { The Heritage Founda- } \\
\text { tion, Wall Street Journal } \\
\text { Index of Economic } \\
\text { Freedom }\end{array}$ \\
\hline
\end{tabular}

Źródło: opracowanie własne. 
Weryfikacji poddano następujące hipotezy badawcze:

1. Różnice w nominalnych stawkach podatku od osób prawnych między krajem inwestora a krajem przyjmującym wpływają pozytywnie na wielkość bezpośrednich inwestycji.

2. Różnice w efektywnych stawkach podatku od osób prawnych między krajem inwestora a krajem przyjmującym wpływaja pozytywnie na wielkość bezpośrednich inwestycji

3. Dystans geograficzny między inwestorem a krajem przyjmującym hamuje inwestycje zagraniczne. Badane kraje Europy Środkowej rozwinęły bardziej aktywne kontakty z zagranicznymi inwestorami z krajów ościennych.

4. Zgodnie z podstawowymi założeniami modelu grawitacyjnego kraje Europy Środkowej promuja bardziej aktywne relacje $\mathrm{z}$ inwestorami $\mathrm{z}$ krajów o większym PKB.

Model grawitacyjny służy do analizy zależności handlu międzynarodowego i jako pierwszego, który zaproponował jego wykorzystanie wskazuje się Tinbergen'a w 1962 roku i Linnemann w 1966 roku. W naukach geograficznych koncepcja ta została wykorzystana w badaniach przestrzenno-ekonomicznych przez m.in. Carey w 1958, Ravenstein w 1885 i 1889 i Janowskiego w 1908. Zaletą tego modelu jest jego wysoka przydatność w analizach empirycznych, albowiem uwzględnia wielkość gospodarek krajowych, koszty przepływu kapitału między dwoma krajami oraz międzynarodowe relacje pozahandlowe. [Gawlikowska-Hueckel, Umiński, 2016, s. 94-95]. Grawitacyjny model handlu zagranicznego można przedstawić za pomocą następującego równania:

$$
\mathrm{T}_{\mathrm{ij}}=\mathrm{K} \frac{\mathrm{PNB}_{\mathrm{i}}^{\alpha} \mathrm{PNB}_{\mathrm{j}}^{\beta}}{\mathrm{DIST}_{\mathrm{ij}}^{\delta}}
$$

gdzie: $\mathrm{T}_{\mathrm{ij}}$ - strumień handlu między krajami i oraz $\mathrm{j}, \mathrm{PNB}_{\mathrm{i}(\mathrm{j})}$ - produkt narodowy brutto kraju i (j), DIST $T_{i j}$ - odległość geograficzna między krajami i oraz j, $\alpha, \beta, \delta$ elastyczności handlu względem produktu narodowego brutto krajów oraz odległości między krajami, K - stała grawitacyjna [Pietrzak, Łapińska, 2014, s. 67].

Zgodnie z zapisem równania, wolumen wymiany handlowej jest w warunkach ceteris paribus proporcjonalny do iloczynu wielkości tych krajów (w sensie PKB lub innej zmiennej obrazującej wielkość rynku) oraz wolumen ten maleje wraz ze wzrostem dystansu między dwoma krajami, który generuje dodatkowe koszty zmniejszające atrakcyjność wymiany handlowej.

Model jest rozszerzany o inne czynniki wspomagające lub utrudniające przepływy handlowe, takie jak członkostwo w umowie o wolnym handlu, a także więzi kulturowe, wspólną kolonialną przeszłość lub wspólny język [Linders, de Groot, 2006, s. 3]. Model ten nie jest związany z formalną teorią na temat BIZ, ale jego empiryczne specyfikacje pozwalaja oprzeć go na założeniach paradygmatu eklektycznego [Altomonte, 2000, s. 82]. Neumayer [Neumayer, 2007] i Barthel $i$ in. [Barthel i in., 2009] wykorzystali rozwinięte równania grawitacyjne w badaniu wpływów podatkowych na BIZ. 
Grupę krajów inwestorów wybrano na podstawie średniego udziału w napływie BIZ do krajów przyjmujących (Czechy, Polska, Słowacja), a ogólny średni udział tych krajów wynosił ponad $75 \%$ w badanym okresie. W rezultacie wytypowano następujące kraje: Holandia, Niemcy, Luksemburg, Francje, Hiszpania, Wielka Brytania, Włochy, Austria, Cypr i Belgia.

TABELA 2.

Napływ BIZ do Polski, Słowacji i Czech

\begin{tabular}{|l|c|c|c|c|c|c|}
\hline \multicolumn{1}{|c|}{ Napływ BIZ ogółem } & $\mathbf{2 0 1 0}$ & $\mathbf{2 0 1 1}$ & $\mathbf{2 0 1 2}$ & $\mathbf{2 0 1 3}$ & $\mathbf{2 0 1 4}$ & $\mathbf{2 0 1 5}$ \\
\hline Czechy & 96152 & 93184 & 103456 & 97311 & 100076 & 107129 \\
\hline Polska & 161378 & 157151 & 178257 & 168506 & 174018 & 167091 \\
\hline Słowacja & 50328 & 40173 & 41780 & 42072 & 40969 & 40129 \\
\hline $\begin{array}{l}\text { Napływ BIZ z krajów } \\
\text { wybranych do badania }\end{array}$ & 2010 & 2011 & 2012 & 2013 & 2014 & 2015 \\
\hline Czechy & 78624 & 74692 & 83627 & 77436 & 79030 & 87320 \\
\hline Polska & 117970 & 118730 & 137492 & 137355 & 145155 & 139913 \\
\hline Słowacja & 39351 & 30055 & 31318 & 30067 & 29148 & 28042 \\
\hline
\end{tabular}

Źródło: opracowanie własne na podstawie danych OECD, Eurostat.

Postać równania grawitacji dla danych panelowych określono jako (wszystkie dane zostały zlogarytmizowane, oprócz zmiennych zerojedynkowych):

$$
\begin{gathered}
\mathrm{BIZ}_{\mathrm{ijt}}=\beta_{1} \mathrm{PKB}_{\mathrm{it}}+\beta_{2} \mathrm{PKB}_{\mathrm{it}}+\beta_{3} \mathrm{PKBP}_{\mathrm{it}}+\beta_{4} \mathrm{PKBP}_{\mathrm{jt}}+\beta_{5} \mathrm{WSKW}_{\mathrm{it}}+\beta_{6} \mathrm{WSKW}_{\mathrm{it}} \\
+\beta_{7} \mathrm{TAX}+\beta_{8} \mathrm{EATR}+\alpha_{1} \mathrm{EUR}+\alpha_{2} \mathrm{GRA}+\gamma_{\mathrm{ODL}}+\varepsilon_{\mathrm{ijt}}
\end{gathered}
$$

gdzie: $\mathrm{BIZ}_{\mathrm{ijt}}$ - jest wektorem wartości zmiennej objaśnianej; $\mathrm{PKB}_{\mathrm{it}}, \mathrm{PKB}_{\mathrm{jt}}, \mathrm{PKBP}_{\mathrm{it}}$, $\mathrm{PKBP}_{\mathrm{it}}, \mathrm{WSKW}_{\mathrm{it}}, \mathrm{WSKW}_{\mathrm{it}}, \mathrm{ODL}_{\mathrm{ij}}$, - sa to wektory wartości zmiennych objaśniających; EUR, GRA - są to wektory wartości zmiennych zerojedynkowych; $\beta_{1}, \beta_{2}, \beta_{3}$, $\beta_{4}, \beta_{5}, \beta_{6}, \beta_{7}, \beta_{8}, \alpha_{1}, \alpha_{2}, \gamma$-sa to parametry strukturalne modelu; $\varepsilon_{i j t}$-stanowi wektor składnika losowego.

\section{Wyniki estymacji i diagnostyka modelu panelowego}

W standardowym zlineralizowanym modelu ujęto jedenaście zmiennych egzogenicznych najbardziej charakterystycznych dla modeli grawitacji, w tym: PKB, PKB per capita, odległość między krajami. W efekcie wykorzystania danych panelowych osiagnięto większą heterogeniczność, a także większą liczbę stopni swobody i efektywność oszacowania.

W celu weryfikacji założenia o jednorodności obiektów wykorzystano test Walda. Wartość statystyki $\mathrm{F}(29,139)=2,05782[0,00302881]$ i na podstawie tego odrzucono hipotezę zerową stwierdzając występowanie zróżnicowania wyrazów wolnych i brak jednorodności poszczególnych obiektów. Test wykluczył wykorzy- 
stanie klasycznej metody najmniejszych kwadratów (KMNK) na rzecz estymatora efektów ustalonych (fixed effect). Weryfikację założenia o stałości wariancji składnika losowego obiektów sprawdzono za pomocą testu Breuscha-Pagana. Wartość statystyki tego testu wyniosła 1,19241 [0,274844], dlatego wariancja składnika losowego efektów indywidualnych jest nieistotnie różna od zera i należałoby wykorzystać estymator KMNK.

Wyniki testów prezentują sprzeczne rezultaty, dlatego w celu rozstrzygnięcia niejednoznaczności zostanie przeprowadzony dodatkowy test za pomocą testu Hausmana [Wojciechowski, Lubacha-Sember, 2013, s. 143]. Z uwagi na statyczny charakter szacowanych modeli panelowych zdecydowano się na wybór testu Hausmana, gdyż w modelu nie ujęto zmiennych opóźnionych w czasie. Także kolejnym argumentem, który zadecydował o przyjęciu takiego podejścia badawczego był relatywnie krótki okres badawczy. W rezultacie otrzymano szeroki dostęp do możliwych metod estymacji.

Badanie rozpoczęto od weryfikacji czy estymatory Fixed effect (dalej FE) i Random effect (dalej RE) są nieobciążone za pomocą testu Hausmana, który porównuje wartości ocen parametrów uzyskanych za pomocą obu estymatorów. Hipoteza zerowa zakłada, że efekty indywidualne są niezależne od zmiennych objaśniających, dlatego oba estymatory są nieobciążone, a oceny parametrów za pomocą obu estymatorów nie powinny się od siebie istotnie różnić. W tej sytuacji bardziej preferowanym i efektywniejszym będzie estymator RE. Natomiast, gdy możemy przyjąć hipotezę alternatywna, że estymator FE jest nieobciążony, a estymator RE jest obciążony, albo gdy pojawił się błąd w specyfikacji modelu to należy wybrać estymator FE do estymacji takiego modelu [Kośko, Osińska, Stempińska, 2007, s. 418]. Statystyka testu Hausmana wyniosła $H=75,2977$ i pozwoliła na odrzucenie hipotezy zerowej (RE) na rzecz alternatywnej (FE), a tym samym wybór estymatora FE. Do obliczeń wykorzystano program ekonometryczny Gretl version $2017 \mathrm{~b}$. Oszacowany model dla danych panelowych jest statycznym modelem liniowym z jednokierunkowym efektem indywidualnym.

Przedstawiony model cechuje się względnie wysokim stopniem wyjaśnienia zmienności zmiennej objaśnianej na poziomie około 75\%. Większość parametrów strukturalnych jest istotnie statystyczna przy poziomie mniejszym niż $0,1 \%$. Zmienne są łącznie istotne i potwierdza to test $\mathrm{F}$.

Estymacja parametrów modelu grawitacji pozwoliła na zbadanie wpływu oddziaływania na napływy BIZ do Polski, Czech i Słowacji wskaźnika ODL. Zmienna ODL określająca odległość geograficzną między krajami jest istotnie statystyczna, a ocena parametru ma wartość ujemną, co wskazuje, że odległość jest destymulanta. Jego wartość dla całej próby wynosi - 0,286482. Zatem hipoteza badawcza, że dystans geograficzny między inwestorem a krajem przyjmującym hamuje inwestycje zagraniczne została potwierdzona. PKB per capita kraju inwestora, określona zmienną $\mathrm{PKPB}_{\mathrm{j}}$, okazała się statystycznie istotna, a ocena parametru posiada wartość ujemną. W wyniku czego ma ona negatywny wpływ na BIZ w tych krajach. Wartość ocen parametru dla całej próby ukształtowała się na poziomie $-7,19282$. Zatem hipoteza badawcza zakłada, że Polska, Czechy i Słowacja promuja bardziej 
aktywne relacje $z$ inwestorami z krajów o większym PKB nie została pozytywnie zweryfikowana. Oprócz tego istotność zmiennej WSKW $W_{j t}$ i jej wartość dodatnia dowodzi, że wolność od ceł i barier pozataryfowych wpływa w istotny sposób na napływ BIZ do Polski, Czech i Słowacji.

TABELA 3.

Wyniki estymacji i parametrów modelu dla BIZ w okresie 2010-2015. Estymacja metodą FE

\begin{tabular}{|c|c|c|c|c|}
\hline Zmienna & Współczynnik & $\begin{array}{l}\text { Odchylenie } \\
\text { standardowe }\end{array}$ & t-Studenta & Wartość p \\
\hline const & $-17,5758$ & 24,9424 & $-0,7047$ & 0,4822 \\
\hline 1_PKB ${ }_{\text {it }}$ & $-0,0214906$ & 0,080135 & $-0,2682$ & 0,789 \\
\hline 1_PKB ${ }_{j \mathrm{t}}$ & $-0,186289$ & 0,567125 & $-0,3285$ & 0,743 \\
\hline $1 \_O D L_{i j}$ & $-0,286482$ & 0,153663 & $-1,864$ & $0,0644^{*}$ \\
\hline 1_PKBP ${ }_{\text {it }}$ & $-0,0219057$ & 0,38159 & $-0,05741$ & 0,9543 \\
\hline 1_PKBP ${ }_{j t}$ & $-7,19282$ & 2,23463 & $-3,219$ & $0,0016^{* * *}$ \\
\hline 1_WSKW & 0,348622 & 1,1974 & 0,2911 & 0,7714 \\
\hline 1_WSKW & 10,9572 & 6,40102 & 1,712 & $0,0892 *$ \\
\hline TAX & 1,67797 & 0,743243 & 2,258 & $0,0255^{* *}$ \\
\hline EATR & $-2,85582$ & 0,725549 & $-3,936$ & $0,0001 * * *$ \\
\hline EUR & 0,912643 & 0,352769 & 2,587 & $0,0107 * *$ \\
\hline GRA & 0,747624 & 0,293822 & 2,544 & $0,0120 * *$ \\
\hline Statystyka testu F & \multicolumn{4}{|c|}{10,29357} \\
\hline Współczynnik R ${ }^{2}$ & \multicolumn{4}{|c|}{0,747614} \\
\hline
\end{tabular}

Symbole istotności: *** $-0,01 ; * *-0,05 ; *-0,1$.

Źródło: obliczenia własne za pomoca programu Gretl.

Mimo wszystko, różnica w nominalnych stawkach podatkowych od przedsiębiorstw pokazuje jak ważnym czynnikiem procesu inwestycyjnego są nominalne stawki podatkowe. Współczynnik różnicy w stawce podatku od osób prawnych wynosi 1,67797. Wyniki badania sugerują, że wzrost różnicy pomiędzy ustawową stawką podatkową inwestora a krajami przyjmującymi zwiększa o 1,68\% BIZ w Polsce, Czechach i Słowacji. Zatem można odrzucić hipotezę mówiącą o pozytywnym wpływie różnicy w stawkach podatkowych od przedsiębiorstw między inwestorem a krajem przyjmującym na bezpośrednie inwestycje zagraniczne. Jednak wyniki wpływu efektywnej różnicy stawek podatku dochodowego pokazują coś odmiennego, gdyż wzrost różnicy pomiędzy efektywną stawką podatkową inwestora a krajami przyjmującymi powoduje spadek bezpośrednich inwestycji zagranicznych. Współczynnik różnicy w stawce podatku od osób prawnych wynosi -2,85582, co czyni go jednym z najistotniejszych czynników lokowania inwestycji w tych krajach. Hipoteza 
mówiąca o pozytywnym wpływie różnicy między efektywnymi stawkami podatku od osób prawnych na bezpośrednie inwestycje zagraniczne nie została potwierdzona.

Wpływ efektywnej różnicy stawek podatku dochodowego jest większy niż rola nominalnej stawki podatku dochodowego od osób prawnych. Jednak obliczenia empiryczne zawarte w tabeli 3. wskazuja, że efektywna stawka podatkowa wpływa na bezpośrednie inwestycje zagraniczne w inny sposób niż nominalna.

\section{Podsumowanie}

Przewaga lokalizacyjna umożliwia czerpanie zysków z obecności na danym rynku, ze względu na m.in system podatkowy. Korporacje transnarodowe są zróżnicowane pod względem kraju pochodzenia, ale także w stosowanej strategii podatkowej. W wymiarze międzynarodowym podatki nie są wprawdzie jedynym czynnikiem decydującym o tym, czy kapitał w formie BIZ zostanie ulokowany w danym kraju. Ważnymi czynnikami są również wolność gospodarcza, wspólna waluta i odległość.

W wyniku przeprowadzonej estymacji parametrów modelu grawitacyjnego opisującego zależności między napływem bezpośrednich inwestycji zagranicznych do państw Europy Środkowej, a pozostałymi zmiennymi dokonano identyfikacji istotnych czynników. Model charakteryzował się wysokim stopniem wyjaśnienia zmienności zmiennej objaśnianej na poziomie około $75 \%$. Zmienne dotyczące odległości, wspólnej granicy i zmian w stawkach podatkowych były istotnie statystycznie. Pozwoliło to na uchwycenie efektu grawitacyjnego i potwierdzenie ujemnej zależności odległości geograficznej. Stwierdzono, że różnice w nominalnych stawkach podatkowych od osób prawnych wpływaja pozytywnie na napływ BIZ do krajów objętych badaniem. Wyniki wpływu efektywnej różnicy stawek podatku dochodowego pokazały coś odmiennego, gdyż wzrost różnicy pomiędzy efektywną stawką podatkowa inwestora a krajami przyjmujacymi powoduje spadek napływu bezpośrednich inwestycji zagranicznych. Dalszym punktem rozważeń będzie wyjaśnienie różnego wpływu nominalnej i efektywnej stawki podatkowej na napływ BIZ oraz określenie wpływu umów o unikaniu podwójnego opodatkowania na napływ BIZ.

\section{Literatura}

Altomonte C., 2000, Economic determinants and institutional frame-works: FDI in economies in transition, "Transnational Corporations", nr 9(2).

Barthel F., Busse M., Neumayer E., 2009, The Impact of Double Taxation Treaties on Foreign Direct Investment: Evidence from Large Dyadic Panel Data, "Contemporary Economic Policy", nr 28(3).

Cžnniki wærostu gospodarczego, 2004, Karaszewski W., Haffer M. (red.), Uniwersytet Mikołaja Kopernika, Torun.

Dunning J. H., Lundan S. M., 2008, Institutions and the OLI paradigm of the multinational enterprise, "Asia Pacific Journal of Management", t. 25. 
Gawlikowska-Hueckel K., Umiński S., 2016, Analiza handlu zagranicそnego Polski w śmietle najnowszych koncepcji teoretycznych, Wydawnictwo Naukowe Scholar, Warszawa.

Guzek M., 2006, Międzynarodowe stosunki gospodarcze. Zarys teorii i polityki handlowej, Wydawnictwo PWE, Warszawa.

Hymer S. H., 1976, The International Operations of National Firms: A Study of Direct Foreign Investment, MIT Press, Cambridge.

Jarczewska-Romaniuk A., 2004, Przedsiębiorstwa międzynarodowe; Oficyna Wydawnicza Branta, Warszawa - Bydgoszcz.

Karaszewski W., 2004, Najwieksze korporacje transnarodowe swiata $i$ ich wplyw na wrost gospodarczy; [w]: Caynniki warostu gospodarczego, W. Karaszewski, M. Haffer (red.), Uniwersytet Mikołaja Kopernika, Toruń.

Karaszewski W., 2004, Bezpośrednie inwestycje zagraniczne. Polska na tle świata, Wydawnictwo Dom Organizatora, Toruń.

Kośko M., Osińska M., Stempińska J., 2007, Ekonometria współczesna, Wydawnictwo Dom Organizatora, Toruń.

Krugman P. R., Obstfeld M., 1997, Miedzynarodowe stosunki gospodarcze, PWN, Warszawa.

Linders G. J. M, de Groot H. L. F., 2006, Estimation of the gravity equation in the presence of zero flows, "Tinbergen institute discussion paper TI 2006-072/3".

Międzynarodowy Fundusz Walutowy, 2009, Balance of Payments and International Investment Position Manual, International Monetary Fund, Washington D.C.

Neumayer E., 2007, Do double taxation treaties increase foreign direct investment to developing countries?, "Journal of Development Studies", nr 43(8).

OECD (Organization for Economic Cooperation and Development), 2008, OECD Benchmark Definition of Foreign Direct Investment, 4th Edition, Paris.

Pach J., 2001, Bezpośrednie inwestycje zagraniczne w świetle bezpieczeństwa ekonomicznego na prayktadzie Polski w latach dziewię́dziesiatych XX wieku, Wydawnictwo Naukowe Akademii Pedagogicznej, Kraków.

Pietrzak M., Łapińska J., 2017, Zastosowanie modelu grawitacji do identyfikacji czynnikón determinujacych przeplywy handlowe w Unii Europejskiej, „Przegląd Statystyczny”, z. 1, http://keii.ue.wroc.pl/przeglad/Rok\%202014/Zeszyt\%201/ 2014_61-1 _065078.pdf [data wejścia: 25.03.2017].

Wojciechowski L., Lubacha-Sember J., 2014, Uwarunkowania przeplywu polskich bezpośrednich inwestycji zagranicznych do krajów Unii Europejskiej. Model grawitacyjny z. wykoraystaniem danych panelowych, „Ekonomia Międzynarodowa”, nr 7.

Zorska A., 1998, Ku globalizacji? Przemiany w korporacjach transnarodowych $i$ w gospodarce swiatowej, PWN, Warszawa. 